RASĀYAN J. Chem.

Vol. 14 | No. 2 |799-810| April - June | 2021 ISSN: 0974-1496 | e-ISSN: 0976-0083 | CODEN: RJCABP http://www.rasayanjournal.com http://www.rasayanjournal.co.in

\title{
AQBD BASED LC-UV METHOD FOR ASSESSMENT OF ANTIVIRAL DRUGS IN TERNARY MIXTURE
}

\author{
J. R. Tulasi ${ }^{1, \bowtie}$, A. Prameela Rani ${ }^{2}$, Pani Kumar Durga Anumolu ${ }^{3}$ \\ ${ }^{1}$ Research scholar, University College of Pharmaceutical Sciences, Acharya Nagarjuna \\ University, Guntur-522510, (Andhra Pradesh) India \\ ${ }^{2}$ Department of Pharmaceutics, University College of Pharmaceutical Sciences, Acharya \\ Nagarjuna University, Guntur-522510, (Andhra Pradesh) India \\ ${ }^{3}$ Department of Pharmaceutical analysis, Gokaraju Rangaraju College of Pharmacy, \\ Hyderabad-500090, (Telangana) India \\ Corresponding Author: tulasikanumuri@gmail.com
}

\begin{abstract}
The current article describes the development of a systematic, science and risk-based stability-indicating LC-UV method for the routine analysis of Ombitasvir, Paritaprevir and Ritonavir in quality control laboratories from its bulk and formulated products. To mark the importance of QbD in the new era comparative results of this with other methods available from literature and validation data were presented. Quality by design approach was employed for optimization of method parameters like Organic phase, $\mathrm{pH}$ and Flow rate. The interaction effect of these parameters on the response variable theoretical plate number was evaluated through contour plots. Development of method was done using PHENOMENOX $\mathrm{C} 18(150 \mathrm{~mm} \times 4.6 \mathrm{~mm}, 5 \mu \mathrm{m}$ particle size $)$ column in isocratic mode using Ammonium acetate buffer ( $\mathrm{pH}$ adjusted to 6) and Acetonitrile $(60: 40 \% \mathrm{v} / \mathrm{v})$ as mobile phase at a detection wavelength of $265 \mathrm{~nm}$ and flow rate of $1.0 \mathrm{ml} / \mathrm{min}$. The three-drug retention times were found to be 3.21 minutes for Ritonavir, 5.71 minutes for Ombitasvir, 6.41 minutes for Paritaprevir. The calibration plots linear regression analysis showed a good linear relationship with $\mathrm{r}^{2}=0.999$ for Ritonavir, $\mathrm{r}^{2}=0.999$ for Ombitasvir, $\mathrm{r}^{2}=0.999$ for Paritaprevir in the range of $12.5-75 \mu \mathrm{g} / \mathrm{ml}, 3.125-18.75 \mu \mathrm{g} / \mathrm{ml}, 18.75-112.5 \mu \mathrm{g} / \mathrm{ml}$ respectively. The HPLC method was applied for quantification of studied drugs in tablets; results agreed with label claim and were validated according to ICH guidelines. This is the first RP-HPLC method reported for the assay of three drugs in bulk and formulations by QbD approach
\end{abstract}

Keywords: AQbD, Ombitasvir, Paritaprevir, Ritonavir, Risk Analysis, Contour Plots.

RASĀYAN J. Chem., Vol. 14, No.2, 2021

\section{INTRODUCTION}

AQbD aids analytical chemists to develop the most cost-effective and robust analytical method, which makes it easy to analyze the drug throughout its lifecycle and also enhances the regulatory flexibility of the method. The software helps in designing a region where the method can be operated easily without altering performance. The Exquisite data obtained from the study of multidimensional space makes it feasible to link method parameters and quality attributes. These sequential multifactor variations were more beneficial than conventional univariate One Factor at A Time (OFAT) approaches. ${ }^{13}$

Ombitasvir chemically known as "methyl N-[(2S)-1-[(2S)-2-(\{4-[(2S,5S)-1-(4-tert-butylphenyl)-5-\{4[(2S)- 1-[(2S)-2-[(methoxycarbonyl)amino]-3-methylbutanoyl]pyrrolidine2amido]phenyl $\}$ pyrrolidine yl]phenyl \}carbomoyl)pyrrolidin-1-yl]-3-methyl-1-oxobutan-2-yl]carbamate" is an inhibitor of the HCV non-basic protein $5 \mathrm{~A}$. It is used in treatment of chronic hepatitis $\mathrm{C}$ infection as part of combination therapy. ${ }^{4}$ Paritaprevir chemically called " $(2 \mathrm{R}, 6 \mathrm{~S}, 12 \mathrm{Z}, 13 \mathrm{aS}, 14 \mathrm{aR}, 16 \mathrm{aS})-\mathrm{N}-($ Cyclopropylsulfonyl)-6- $\{[(5-$ methyl-2- pyrazinyl)carbonyl]amino\}-5,16-dioxo-2-(6-phenanthridinyloxy) $1,2,3,6,7,8,9,10,11,13 \mathrm{a}, 14,15,16,16$ atetradecahydrocyclopropa[e]pyrrolo[ 1,2$][1,4]$ diazacyclopentadecine14 a $(5 \mathrm{H})$-carboxamide" is a powerful inhibitor of the serine protease NS3/4A and is taken as a combination therapy to treat chronic hepatitis C. ${ }^{5}$

Ritonavir chemically named as "1,3-thiazol-5-ylmethyl N-[(2S,3S,5S)-3-hydroxy-5-[(2S)-3-methyl-2$\{[$ methyl(\{[2-(propan-2-yl)-1,3-thiazol-4-yl]methyl $\}$ )carbamoyl]amino $\}$ butanamido]-1,6 -diphenylhexan2-yl]carbamate" was once known as a most complex inhibitor of HIV protease. ${ }^{17}$ But in the present

Rasayan J. Chem., 14(2), 799-810(2021)

http://dx.doi.org/10.31788/ RJC.2021.1426139

This work is licensed under a CC BY 4.0 license. 
RASĀYAN J. Chem.

Vol. 14 | No. 2 |799-810| April - June | 2021

scenario it is seldom used for its antiviral activity and widely used as a symbiotic to other protease inhibitors. More prominently, Ritonavir in low dose is used to inhibit a liver enzyme cytochrome P4503A4 (CYP3A4) that usually metabolizes protease inhibitors. Thus the drug plays a significant role in enhancing other protease inhibitors activity. ${ }^{6-8}$ A thorough review of literature disclosed quite a few publications on LC-UV method development strategy but the design of experiment approach for Liquid chromatography specifically focused on pharmaceutical analytical method development in a Quality by design environment for simultaneous assessment of Anti-viral drugs such as Ombitasvir, Paritaprevir and Ritonavir have not been reported. ${ }^{11,12,19,21-24}$

\section{EXPERIMENTAL}

\section{Chemicals and Reagents}

Ombitasvir, Paritaprevir, Ritonavir were obtained as gift samples from Hetero drugs private Limited. (Hyderabad, India). Samples of tablets were obtained from a Local pharmacy (Hyderabad, India), Potassium dihydrogen orthophosphate, Triethyl amine, Orthophosphoric acid, Sodium hydroxide, Hydrochloric acid, Ammonium acetate, Hydrogen peroxide (AR Grade) and Methanol HPLC Grade were procured from Ranchem laboratories.

\section{Instrumentation and Chromatographic Conditions}

Reverse phase Waters HPLC2695 series having Phenomenex C18 column $(150$ x $4.6 \mathrm{~mm}, 5 \mu)$ was used for chromatographic separations. ACN: Ammonium acetate buffer (pH adjusted to 6.0) in the ratio of 40:60 delivered at a flow rate of $1 \mathrm{ml} / \mathrm{min}$ was the optimized mobile phase. Filtration through $0.45-\mu \mathrm{m}$ Whatman filter paper and sonication for $20 \mathrm{~min}$ was further done to improvise the method. Analysis was performed at ambient temperature, and the elution of the compounds was monitored by diode array detection (DAD) from 190 to $400 \mathrm{~nm}$. At $265 \mathrm{~nm}$ a $10 \mu 1$ volume of sample was injected to record the chromatogram.

\section{Drug Authentication Studies}

Preliminary drug authentication studies were performed using $10 \mu \mathrm{g} / \mathrm{ml}$ solution in melting point apparatus, $\mathrm{kBr}$ pellet technique employed Shimadzu FT-IR IR spectroscopy and Shimadzu UV-1800 Uv spectroscopy in the range of $190-400 \mathrm{~nm} \cdot{ }^{1-3,9-11,19,22,23}$

\section{Sample Processing \\ Diluents}

The drug was primarily dissolved in ammonium acetate and diluted with Acetonitrile and Water in the ratio of 50:50.

\section{Preparation of Standard Stock Solutions}

Precisely measured quantities of Ritonavir (50 mg), Ombitasvir (12.5 mg) and Paritaprevir (75 mg) were transferred to three $100 \mathrm{ml}$ volumetric flasks. To the above flasks, $10 \mathrm{ml}$ of ammonium acetate was added and sonicated for 15mins. Volumes were made up with water and acetonitrile in the ratio of 50:50 and marked as Standard stock arrangement 1,2and 3.

\section{Preparation of Standard Working Solutions (100\% Solution)}

$1 \mathrm{ml}$ from every stock solution was pipetted out and brought into a $10 \mathrm{ml}$ volumetric flask. Then the flask was filled up with 50:50 Water and acetonitrile till the mark.

\section{Preparation of Sample Stock Solutions}

20 tablets were weighed and the typical weight of each tablet was calculated, then the load corresponding to one tablet was transferred into a $10 \mathrm{~mL}$ volumetric flask. $6 \mathrm{~mL}$ of diluent was added and the solution was sonicated for twenty-five minutes, further, the volume was filled up to the mark with diluent and filtered.

\section{Preparation of Sample Working Solutions (100\% Solution)}

$1 \mathrm{ml}$ of the above-filtered solution was taken out into a $10 \mathrm{ml}$ volumetric flask and brimmed up to the mark with diluents to prepare $50 \mathrm{ppm}, 12.5 \mathrm{ppm}$ and $75 \mathrm{ppm}$ concentration solutions. 
RASĀYAN J. Chem.

Vol. 14 | No. 2 |799-810| April - June | 2021

Preparation of Buffer: 0.01N Ammonium Acetate Buffer

In a $1000 \mathrm{ml}$ volumetric flask, $0.78 \mathrm{gm}$ of Ammonium acetate and $900 \mathrm{ml}$ of milli-Q water were added. The solution was sonicated and finally filled up to the mark and then $\mathrm{pH}$ was adjusted to 3 with orthophosphoric acid solution.

\section{Design of Experiments}

Design of experiments (DoE) is a statistical tool where we can create a feasible arena to alter the method inputs without a prominent effect on analytical method outputs. The experimental tool also aims at process optimization which decodes the hierarchal levels of most influential parameters by risk ranking and provides a scientific base to properly link the dependent and independent variables. The Sigma tech software, design of experiments was performed to screen a large database of parameters that affect quality attributes. The selected significant factors (\% organic phase, aqueous phase $\mathrm{PH}$ and flow rate) that topped the influential parameters list were further optimized using a central composite design. The lower and upper values of these three factors reported in (Table -1) were then placed in the sigma tech software and 8 experimental trials were obtained (Table-2).

Table-1: Optimization of Variables Depicting Lower and Higher Values for Method Parameters

\begin{tabular}{c|c|c|c|c|c}
\hline S. No. & Variable & Variable Name & Units & Low Value & High Value \\
\hline 1 & $\mathrm{X} 1$ & Organic phase & $\%$ & 30 & 70 \\
\hline 2 & $\mathrm{X} 2$ & Buffer $(\mathrm{pH})$ & Number & 3 & 7 \\
\hline 3 & $\mathrm{X} 3$ & Flow rate & $\mathrm{m} 1 / \mathrm{min}$ & 0.6 & 1 \\
\hline
\end{tabular}

Table-2: System Given Trial Chart

\begin{tabular}{c|c|c|c|c}
\hline Exp. No. & Combination & $\mathrm{X} 1$ & $\mathrm{X} 2$ & $\mathrm{X} 3$ \\
\hline 1 & $\mathrm{I}$ & 30 & 3 & 0.6 \\
\hline 2 & $\mathrm{X} 1$ & 70 & 3 & 0.6 \\
\hline 3 & $\mathrm{X} 2$ & 30 & 7 & 0.6 \\
\hline 4 & $\mathrm{X} 1 \mathrm{X} 2$ & 70 & 7 & 0.6 \\
\hline 5 & $\mathrm{X} 3$ & 30 & 3 & 1.0 \\
\hline 6 & $\mathrm{X} 1 \mathrm{X} 3$ & 70 & 3 & 1.0 \\
\hline 7 & $\mathrm{X} 2 \mathrm{X} 3$ & 30 & 7 & 1.0 \\
\hline 8 & $\mathrm{X} 1 \mathrm{X} 2 \mathrm{X} 3$ & 70 & 7 & 1.0 \\
\hline
\end{tabular}

Method Development by RP-HPLC

\section{Preparation of Buffer (pH 3.0 Buffer)}

Accurately Weighed quantity $(0.78 \mathrm{~g})$ of $0.01 \mathrm{~N}$ ammonium acetate and $400 \mathrm{~mL}$ of triple distilled water was taken in a $1000 \mathrm{ml}$ volumetric flask and $\mathrm{pH}$ was adjusted to 3.0 with orthophosphoric acid.

\section{Mobile Phase}

Filtered and sonicated Acetonitrile and ammonium acetate buffer solution in the ratio of $50: 50 \% \mathrm{v} / \mathrm{v}, \mathrm{pH}$ monitored at 3.0 was optimized as mobile phase.

\section{Preparation of Standard Stock Solution}

Accurately weigh and transfer $10 \mathrm{mg}$ of each standard drug into three different $10 \mathrm{ml}$ of volumetric flasks. $7 \mathrm{~mL}$ of diluents was added, sonicated to dissolve and diluted to the mark with diluent. (Concentration of each drug was found to be as $1000 \mu \mathrm{g} / \mathrm{mL}$ ).

\section{Preparation of Standard Working Solutions}

Further $0.2 \mathrm{~mL}$ from each of the above standard stock solution was transferred to a $10 \mathrm{~mL}$ volumetric flask, diluted up to the mark with diluent and mixed well. The Concentration of ombitasvir, Paritaprevir and Ritonavir was $20 \mu \mathrm{g} / \mathrm{ml}$ in the working solution prepared. ${ }^{14-16}$

\section{QbD Trial Chart}

The trials suggested by the system were performed using waters HPLC 2695 series system with RP C18Phenomenex column ( $250 \mathrm{~mm}$ x $4.6 \mathrm{~mm}$ x $5 \mu$ ) at PDA detection wavelength $265 \mathrm{~nm}$ and corresponding chromatograms were mentioned in results and discussion. 


\section{RASĀYAN J. Chem.}

Vol. 14 | No. 2 |799-810| April - June | 2021

Validation of RP-HPLC Method for Determination of Antiviral Drugs in Combined Dosage Form

Validation is a process of Establishing documented evidence which provides a high degree of assurance that a specific activity will consistently produce the desired result (or) product meeting its pre-determined specifications and quality attributes. ${ }^{18,20}$

The following parameters were considered for the analytical method validation of title ingredients as per ICH Q2 (R1) guidelines. ${ }^{25}$

\section{System Suitability Parameters}

System suitability test aids in justifying the resolution and reproducibility of the chromatographic system. The tests were performed by collecting data from six replicate injections of standard drug solution. It was carried out for the parameters like plate number $(\mathrm{N})$, resolution $(\mathrm{R})$, and tailing factor.

\section{Specificity}

The specificity of the method was assessed by comparing the spectra obtained from the commercial formulations and the synthetic mixture of standard solutions. The chromatograms of blank, placebo, standard and commercial formulations were examined to see the absence of additional peaks at the retention time of Ombitasvir, Paritaprevir and Ritonavir.

\section{Precision}

The precision of the developed method was assessed in terms of repeatability by analyzing six replicate injections of the mixed standard solution of Ombitasvir, Paritaprevir and Ritonavir.

\section{Preparation of Standard Stock Solutions}

Accurately weighed quantity of drugs Ritonavir (50mg), Ombitasvir $(12.5 \mathrm{mg})$ and Paritaprevir $(75 \mathrm{mg})$ were transferred to three $100 \mathrm{ml}$ volumetric flasks separately. $10 \mathrm{ml}$ of methanol was added to flasks and sonicated for $15 \mathrm{mins}$. Flasks were filled up with water and acetonitrile (50:50) and labeled as Standard stock solutions 1, 2 and 3. From each standard stock solution, $1 \mathrm{ml}$ was taken into a $10 \mathrm{ml}$ volumetric flask and made up with diluents to prepare the working standards.

\section{Preparation of Sample Stock Solutions}

In a $100 \mathrm{ml}$ flask, $30 \mathrm{ml}$ diluent and weight equivalent of one tablet was added and sonicated for $25 \mathrm{~min}$, then the flask was brimmed up with diluents and filtered.

To prepare working standard, $1 \mathrm{ml}$ of filtered sample stock solution was transferred to a $10 \mathrm{ml}$ volumetric flask and filled up with diluents.

\section{Linearity}

Ombitasvir, Paritaprevir, and Ritonavir solutions in the concentration range of 3.125-18.75 $\mu \mathrm{g} / \mathrm{ml}, 18.75$ $112.5 \mu \mathrm{g} / \mathrm{ml}, 12.5-75 \mu \mathrm{g} / \mathrm{ml}$ respectively were prepared by suitable dilution of standard stock solution with the diluent. $20 \mu \mathrm{L}$ of samples were then injected at each concentration level and a calibration curve was constructed by plotting the peak area against the concentration of the drug.

\section{Accuracy}

Preparation of Spiked Solution: $0.5 \mathrm{ml}, 1 \mathrm{ml}, 1.5 \mathrm{ml}$ of sample stock solutions were taken into three $10 \mathrm{ml}$ volumetric flasks, to that $1.0 \mathrm{ml}$ from each standard stock solution was added, and made up to the mark with diluents to prepare $50 \%, 100 \%, 150 \%$ spiked solution.

\section{Robustness}

The optimized HPLC conditions set for this method have been slightly modified for samples of Ombitasvir, Paritaprevir and Ritonavir. The small changes include the change in flow rate $( \pm 0.1$ $\mathrm{mL} / \mathrm{min})$, mobile phase $( \pm 5)$ and temperature $\left( \pm 5^{\circ} \mathrm{C}\right)$.

\section{Limit of Detection (LOD) and Limit of Quantification (LOQ)}

The limit of detection (LOD) and limit of quantification (LOQ) procedures were performed on a sample containing very low concentrations of analytes (Ombitasvir, Paritaprevir and Ritonavir) under the ICH guidelines. From the linearity data the limit of detection and quantification was calculated using the following formula. 
RASĀYAN J. Chem.

Vol. 14 | No. 2 |799-810| April - June | 2021

$$
L O D=\frac{3.3 \sigma}{S}
$$

$\sigma=$ standard deviation of the response $S=$ slope of the calibration curve of the analytes

The quantification limit (LOQ) may be expressed as:

$$
L O Q=\frac{10 \sigma}{S}
$$

$\sigma=$ standard deviation of the response $\mathrm{S}=$ slope of the calibration curve of the analytes

\title{
Degradation Studies \\ Oxidation, Acid degradation, Alkali Degradation
}

$1 \mathrm{ml}$ of $20 \%$ hydrogen peroxide $\left(\mathrm{H}_{2} \mathrm{O}_{2}\right), 1 \mathrm{ml}$ of $2 \mathrm{~N}$ Hydrochloric acid, $1 \mathrm{ml}$ of $2 \mathrm{~N}$ sodium hydroxide solutions were added separately to $1 \mathrm{ml}$ of stock solutions of Ritonavir, Ombitasvir and Paritaprevir. The solutions were kept for $30 \mathrm{~min}$ at $60^{\circ} \mathrm{c}$ before further analysis.

\section{Dry Heat Degradation Studies}

The standard drug solution was placed in an oven at $105^{\circ} \mathrm{c}$ for $1 \mathrm{hr}$ to study dry heat degradation.

\section{Photo Stability Studies}

The photochemical stability of the drug was also studied by exposing the $500 \mathrm{ppm} \& 125 \mathrm{ppm} \& 750$ ppm solution to UV light by keeping the beakers in UV Chamber for one day or at 200 Watt-hours $/ \mathrm{m}^{2}$ power photostability chamber.

\section{Neutral Degradation Studies}

Stress testing under neutral conditions was studied by refluxing the drug in water for $6 \mathrm{hrs}$ at a temperature of $60^{\circ}$.

For HPLC stability study $10 \mu 1$ of the resultant solution $(50 \mathrm{ppm} \& 12.5 \mathrm{ppm} \& 75 \mathrm{ppm}$ of all components) were injected into the system and the chromatograms were recorded.

\begin{abstract}
Assay
In a mortar and pestle, twenty tablets of marketed formulation (TECHNIVIE) were weighed, crushed and mixed. Accurately weighed portion of the powder equivalent to one tablet and $20 \mathrm{ml}$ acetonitrile was taken into $25 \mathrm{ml}$ volumetric flask and sonicated for $15 \mathrm{~min}$, filtered through $0.45 \mu \mathrm{m}$ membrane to complete the dissolution of Ombitasvir, Paritaprevir and Ritonavir. From the filtrate, $1 \mathrm{ml}$ was transferred into $10 \mathrm{ml}$ volumetric flask and the volume was made up to the mark with mobile phase to yield concentrations of each of the three drugs in the range of linearity previously described. $10 \mu \mathrm{L}$ of the above-prepared solutions $(n=6)$ were injected into the HPLC system by using optimized chromatographic condition and chromatograms were recorded. The results were represented in Table-10.
\end{abstract}

\section{Preliminary Studies}

\section{RESULTS AND DISCUSSION}

Authentication of drugs was confirmed by determination of melting point, UV absorption spectra $\left(\lambda_{\max }\right)$ and principal peaks in FT-IR. Results of these studies were compared with the reference values and found to be within the limit of acceptance. The individual standard solutions $(10 \mu \mathrm{g} / \mathrm{mL})$ of three drugs when analyzed in UV spectrophotometer in the range of $200 \mathrm{~nm}-400 \mathrm{~nm}$, the wavelength $267 \mathrm{~nm}$ was found apt to get maximum responses for three analytes by the liquid chromatographic method.

\section{Screening Studies}

To determine optimum chromatographic conditions, selected variables were screened using a factorial experimental design. Software designed eight experimental trials given under Table- 2 of materials and methods were performed concerning three variables such as \% organic phase (X1), aqueous phase $\mathrm{PH}$ (X2) and flow rate (X3) to obtain theoretical plate number as method control response for ombitasvir, 
RASĀYAN J. Chem.

Vol. 14 | No. 2 |799-810| April - June | 2021

Paritaprevir and Ritonavir. The average of theoretical plates obtained by performing all the above 8 trials was noted in Table-3 and optimization analysis was executed as reported in Table-4.

Table-3: Eight Experimental Trials designed by Sigma Tech Software and its response recorded as theoretical plate

\begin{tabular}{c|c|c|c|c|c|c|c}
\hline S. No. & Combination & $\mathrm{X} 1$ & $\mathrm{X} 2$ & $\mathrm{X} 3$ & $\begin{array}{c}\text { Theoretical } \\
\text { Plates(OMB) }\end{array}$ & $\begin{array}{c}\text { Theoretical } \\
\text { Plates(PAR) }\end{array}$ & $\begin{array}{c}\text { Theoretical } \\
\text { Plates(RIT) }\end{array}$ \\
\hline 1 & $\mathrm{I}$ & 30 & 3.0 & 0.6 & 3037.7 & 1000.0 & 3417.5 \\
\hline 2 & $\mathrm{X} 1$ & 70 & 3.0 & 0.6 & 3343.3 & 4043.2 & 1665.2 \\
\hline 3 & $\mathrm{X} 2$ & 30 & 7.0 & 0.6 & 8249.5 & 8089.1 & 9500.2 \\
\hline 4 & $\mathrm{X} 1 \mathrm{X} 2$ & 70 & 7.0 & 0.6 & 3678.1 & 4536.2 & 2457.8 \\
\hline 5 & $\mathrm{X} 3$ & 30 & 3.0 & 1.0 & 4050.0 & 5000.0 & 4381.2 \\
\hline 6 & $\mathrm{X} 1 \mathrm{X} 3$ & 70 & 3.0 & 1.0 & 3338.7 & 3299.4 & 1591.5 \\
\hline 7 & $\mathrm{X} 2 \mathrm{X} 3$ & 30 & 7.0 & 1.0 & 13293.5 & 7245.6 & 1394.5 \\
\hline 8 & $\mathrm{X} 1 \mathrm{X} 2 \mathrm{X} 3$ & 70 & 7.0 & 1.0 & 3960.9 & 1359.4 & 2127.3 \\
\hline
\end{tabular}

Table-4: Optimization Analysis

\begin{tabular}{c|c|c|c|c|c|c|c}
\hline & Combination & Coefficient & SS Ratio & Coefficient & SS Ratio & Coefficient & SS Ratio \\
\hline 1 & $\mathrm{~b}_{0}$ & 5369.0 & 0 & 3759.112 & - & 3316.9 & - \\
\hline 2 & $\mathrm{~b}_{1}$ & -1788.75 & $28.024 \%$ & -479.5625 & $2.897 \%$ & -1356.45 & $28.90 \%$ \\
\hline 3 & $\mathrm{~b}_{2}$ & 1926.57 & $32.509 \%$ & 1548.465 & $34.381 \%$ & 553.05 & $4.804 \%$ \\
\hline 4 & $\mathrm{~b}_{1} \mathrm{~b}_{2}$ & -1687.32 & $24.936 \%$ & -1910.212 & $52.319 \%$ & -220.95 & $0.767 \%$ \\
\hline 5 & $\mathrm{~b}_{3}$ & 791.775 & $5.490 \%$ & -658.012 & $6.208 \%$ & -943.275 & $13.98 \%$ \\
\hline 6 & $\mathrm{~b}_{1} \mathrm{~b}_{3}$ & -722.225 & $4.568 \%$ & -322.137 & $1.487 \%$ & 842.225 & $11.14 \%$ \\
\hline 7 & $\mathrm{~b}_{2} \mathrm{~b}_{3}$ & 539.85 & $2.552 \%$ & -347.062 & $1.727 \%$ & -1165.575 & $21.35 \%$ \\
\hline 8 & $\mathrm{~b}_{1} \mathrm{~b}_{2} \mathrm{~b}_{3}$ & -468.0 & $1.918 \%$ & -261.187 & $0.978 \%$ & 1101.571 & $19.06 \%$ \\
\hline
\end{tabular}

SS-Sum of Squares; F-significance Value: b1-Organic phase; b2-\%aqueous phase effect; b3-Flow rate effect on drugs

The positive value of the coefficient of respective drugs in Table- 4 indicates the favorable response and the negative value indicates the inverse effect among the variable and the response respectively. Following conclusions were drawn from the results

\section{Ombitasvir}

The highest SS ratio $(32.5092 \%)$ was obtained at $\mathrm{b}_{2}$ combination so, the $\mathrm{pH}$ of the buffer was the main variable. The positive sign of the coefficient indicates a favorable response. The next highest SS ratio $(28.0242 \%),(24.9363 \%)$ with the negative sign was obtained at $b_{1}$ and $b_{12}$ combination. So \% organic phase, the interaction between \%organic phase (X1) and $\mathrm{pH}$ of the mobile phase (X2) has a negative influence on the response of the chromatographic system.

\section{Paritaprevir}

The highest SS ratio (52.319\%) with a negative sign for this drug was obtained at $\mathrm{b}_{12}$ combination, so the Interaction of \% organic phase and $\mathrm{pH}$ of the buffer on chromatographic conditions was inversely proportional. The SS ratio (34.381\%) was obtained at $\mathrm{b}_{2}$, so the $\mathrm{pH}$ of the buffer was also an important factor. The positive sign of the coefficient indicates that higher the $\mathrm{pH}$ of the buffer, higher the response of the chromatographic system. The SS ratio $(6.208 \%)$ was obtained at $b_{3}$ combination so, the flow rate was also an important factor. The negative sign of the coefficient indicates that lower the flow rate, the better the response of the chromatographic system.

\section{Ritonavir}

The highest SS ratio (28.9017 \%) was obtained at $b_{1}$ combination followed by $b_{23}(21.3474 \%)$ and $b_{123}$ (19.0609) enumerating the negative influence of the Organic phase as well as the interaction between $\mathrm{pH}$ and flow rate. It also signifies the importance of the impact of all three factors interaction. 
RASĀYAN J. Chem.

Vol. 14 | No. 2 |799-810| April - June | 2021

\section{Central Composite Plan of Anti-Viral Drugs}

Analysis of results showed curvature effect was significant. The curvature effect showed $95 \%$ confidence level. This indicates $\mathrm{X} 1, \mathrm{X} 2$, and X3 along with interactions was highly significant at $95 \%$ confidence level. Hence it was mandatory to select a central composite design. The central composite design plan of Ombitasvir, Paritaprevir and Ritonavir with their responses (Theoretical plate number) reported in table No 5 and contour plots were plotted keeping flow rate constant, varying \%organic phase and $\mathrm{pH}$ as shown in Figure-1,2 and 3. The plot shows the significance of \% organic phase at $-2 \mathrm{~L}(40 \%)$ and aqueous phase $\mathrm{pH}$ at $+2 \mathrm{~L}$ level (6) in increasing theoretical plate number.

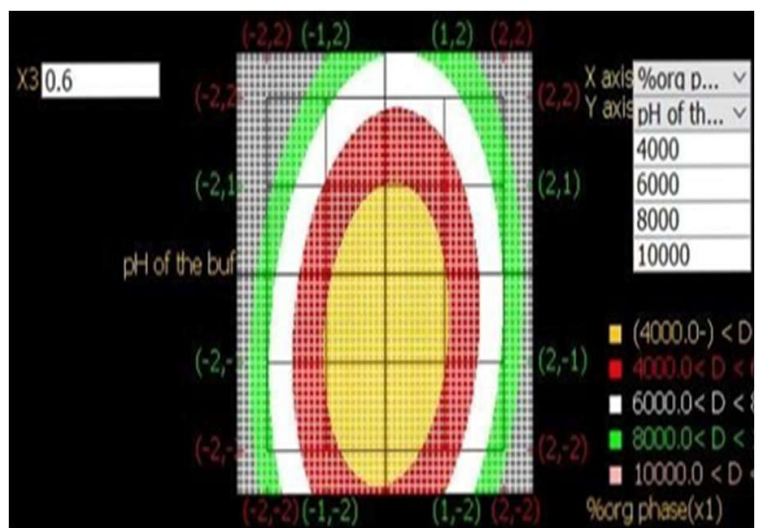

Fig.-1: Contour Plot of Ombitasvir at $0.6 \mathrm{~mL}$ Flow Rate ( $\mathrm{pH}$ between 3-7 and \% Organic Phase between 30-70 $\%)$ preferred

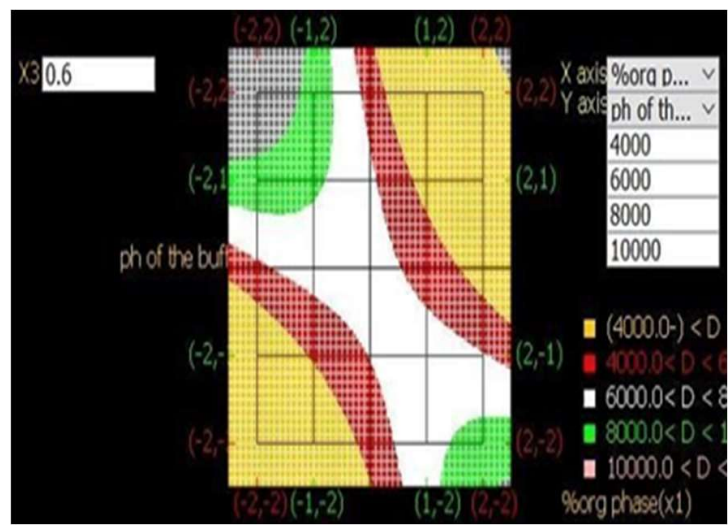

Fig.-2: Contour Plot of Paritaprevir at $0.6 \mathrm{~mL}$ Flow Rate ( $\mathrm{pH}$ between 6-7 and \% Organic Phase between 30-60 $\%)$

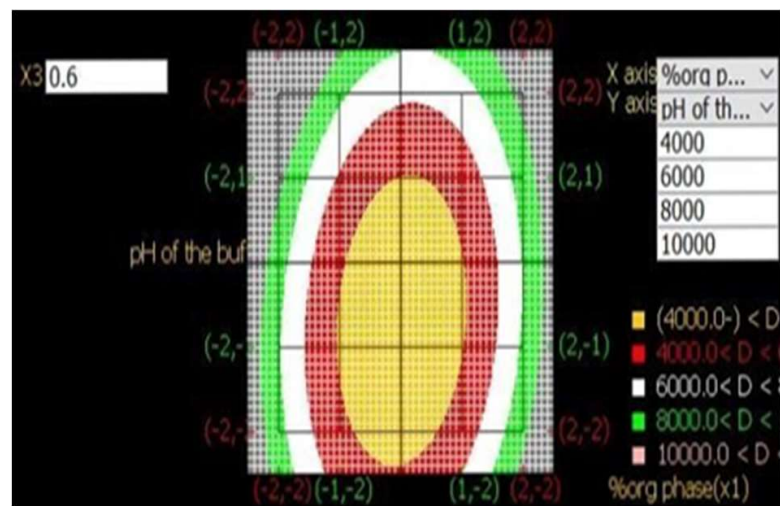

Fig.-3: Contour Plot of Ritonavir at 0.6 mL Flow Rate (pH between 3-7 and \% Organic Phase between 40-60 \%)

Table-5: Central Composite Design

\begin{tabular}{c|c|c|c|c|c|c|c}
\hline S. No. & Trials & $\begin{array}{c}\text { Organic } \\
\text { Phase }\end{array}$ & $\mathrm{pH}$ & Flow Rate & $\mathrm{TP1}$ & $\mathrm{TP2}$ & $\mathrm{TP3}$ \\
\hline 1 & $\mathrm{I}$ & 30 & 3 & 0.6 & 3037.7 & 1000 & 3417.5 \\
\hline 2 & $\mathrm{X} 1$ & 70 & 3 & 0.6 & 3343.3 & 4043.2 & 1665.2 \\
\hline 3 & $\mathrm{X} 2$ & 30 & 7 & 0.6 & 8249.8 & 8089.1 & 9500.2 \\
\hline 4 & $\mathrm{X} 1 \mathrm{X} 2$ & 70 & 7 & 0.6 & 3678.1 & 4536.2 & 2457.8 \\
\hline 5 & $\mathrm{X} 3$ & 30 & 3 & 1.0 & 4050.0 & 5000.0 & 4381.2 \\
\hline 6 & $\mathrm{X} 1 \mathrm{X} 3$ & 70 & 3 & 1.0 & 3338.7 & 3299.4 & 1591.5 \\
\hline 7 & $\mathrm{X} 2 \mathrm{X} 3$ & 30 & 7 & 1.0 & 13293.5 & 7245.6 & 1394.5 \\
\hline 8 & $\mathrm{X} 1 \mathrm{X} 2 \mathrm{X} 3$ & 70 & 7 & 1.0 & 3960.9 & 1359.4 & 2127.3 \\
\hline 9 & $\mathrm{MID} \mathrm{POINT}$ & 50 & 5 & 0.8 & 5504.97 & 7028.32 & 1709.85 \\
\hline 10 & $\mathrm{X} 1-2 \mathrm{~L}$ & 10 & 5 & 0.8 & 5565.8 & 6890.4 & 1671.6 \\
\hline 11 & $\mathrm{X} 1+2 \mathrm{~L}$ & 90 & 5 & 0.8 & 500 & 500 & 12356.6 \\
\hline 12 & $\mathrm{X} 2-2 \mathrm{~L}$ & 50 & 1 & 0.8 & 7487.9 & 8478.3 & 6106.5 \\
\hline
\end{tabular}


RASĀYAN J. Chem.

Vol. 14 | No. 2 |799-810| April - June | 2021

\begin{tabular}{c|c|c|c|c|c|c|c}
\hline 13 & $\mathrm{X} 2+2 \mathrm{~L}$ & 50 & 9 & 0.8 & 800 & 500 & 700 \\
\hline 14 & $\mathrm{X} 3-2 \mathrm{~L}$ & 50 & 5 & 0.4 & 9807.7 & 10788.9 & 7310.6 \\
\hline 15 & $\mathrm{X} 3+2 \mathrm{~L}$ & 50 & 5 & 1.2 & 5542.2 & 6740.3 & 4717.4 \\
\hline
\end{tabular}

X1 Organic Phase; X2 \%aqueous Phase; X3-Flow Rate; TP1, TP2, TP3- Theoretical Plate Number of OMB, PAR, and RIT.

\section{Method Optimization}

After a series of trials at different chromatographic conditions, the method was optimized using HPLC 2695 series with quaternary pump in combination with photodiode array detector and validated. To optimize the HPLC parameters, several mobile phase compositions, changes in flow rate were attempted. Satisfactory separation of the drugs was obtained by Phenomenex RP18 $(150 \times 4.6 \mathrm{~mm}, 5 \mu)$ column eluted with acetonitrile and buffer $(0.01 \mathrm{~N}$ ammonium acetate of $\mathrm{pH} 6.0)$ in the ratio of $(40: 60 \% \mathrm{v} / \mathrm{v})$ at a flow rate of $1.0 \mathrm{ml} / \mathrm{min}$ with a detection wavelength of $265 \mathrm{~nm}$, column temperature of $30^{\circ} \mathrm{C}$ and injection volume of $20 \mu \mathrm{l}$ for ombitasvir, Paritaprevir, and Ritonavir. The retention time was found to be 3.2 minutes for Ritonavir, 5.7 minutes for ombitasvir, 6.4 minutes for Paritaprevir. The optimized chromatogram and results were presented in Table-6 and Fig.-4.

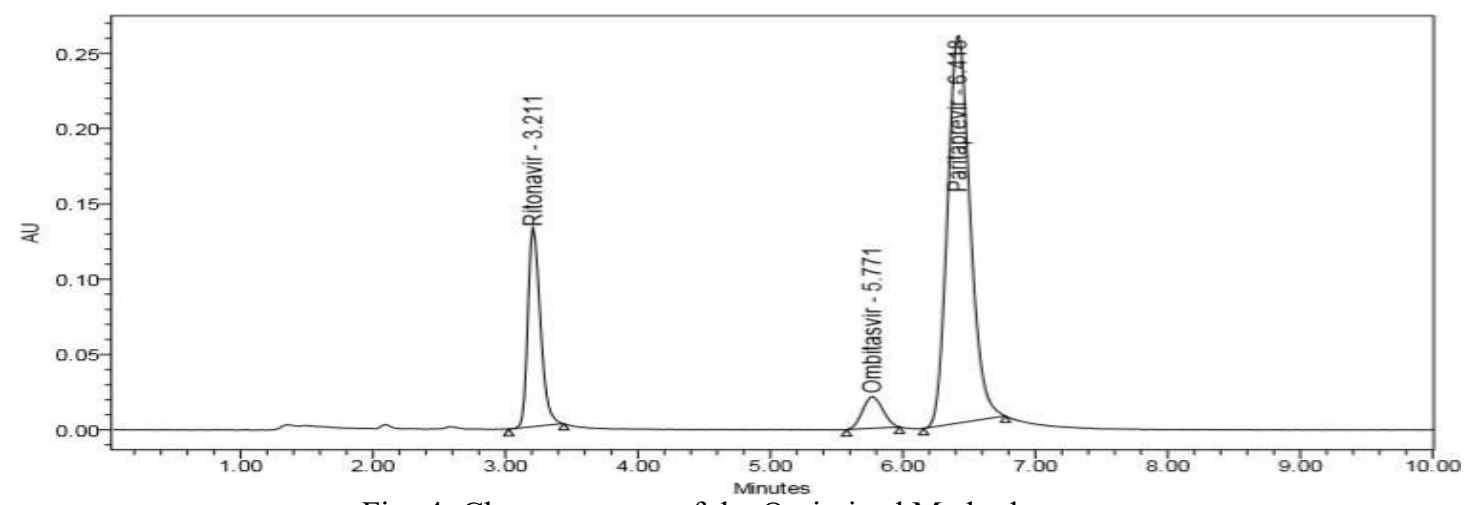

Fig.-4: Chromatogram of the Optimized Method

Table-6: Optimized Chromatographic Condition

\begin{tabular}{c|c}
\hline Parameter/Conditions & Description/Values \\
\hline Column & Phenomenex RP18 $(150 \times 4.6 \mathrm{~mm}, 5 \mu)$ \\
\hline Detector & Photodiode array Detector \\
\hline Flow rate & $1.0 \mathrm{~mL} / \mathrm{min}$ \\
\hline Injection volume & $10 \mu \mathrm{L}$ \\
\hline Wavelength & $265 \mathrm{~nm}$ \\
\hline Column Temperature & $30^{\circ} \mathrm{C}$ \\
\hline Run time & $10 \mathrm{~min}$ \\
\hline Buffer & Ammonium acetate buffer $(\mathrm{pH}$ adjusted to 6.0) \\
\hline Mobile phase & ACN: Buffer(40:60)
\end{tabular}

\section{Method Validation}

The method was validated for all validation parameters as per ICH guidelines. The Linear regression data, mean recovery at three concentration levels $(50 \%, 100 \%, 150 \%)$, intraday and interlay precision, LOD, LOQ for the drugs ombitasvir, Paritaprevir, Ritonavir were reported in Table-7.

Table-7: Validation Parameters of Ombitasvir, Paritaprevir, and Ritonavir

\begin{tabular}{c|c|c|c}
\hline & Ombitasvir & Paritaprevir & Ritonavir \\
\hline Concentration range $\mu \mathrm{g} / \mathrm{mL}$ & $3.125-18.75$ & $18.75-112.5$ & $12.5-75$ \\
\hline Regression equation & $\mathrm{y}=10266 \mathrm{x}+1003$ & $\mathrm{y}=27264 \mathrm{x}+7846$ & $22722 \mathrm{x}+7781$ \\
\hline Correlation coefficient & 0.999 & 0.999 & 0.999 \\
\hline Mean recovery & $99.99 \%$ & $100.24 \%$ & $99.83 \%$ \\
\hline
\end{tabular}


RASĀYAN J. Chem.

Vol. 14 | No. 2 |799-810| April - June | 2021

\begin{tabular}{c|c|c|c}
\hline Intraday precision(\%RSD) & 0.3 & 0.4 & 0.9 \\
\hline Interday precision(\%RSD) & 0.8 & 0.9 & 1.1 \\
\hline LOD $(\mu \mathrm{g} / \mathrm{mL})$ & 0.004 & 0.107 & 0.023 \\
\hline LOQ $(\mu \mathrm{g} / \mathrm{mL})$ & 0.0121 & 0.324 & 0.069 \\
\hline
\end{tabular}

\section{System Suitability}

System suitability criteria include such factors as plate count, tailing factor, retention and resolution. The data for system suitability parameters were reported in Table-8.

Table-8: System Suitability Parameters of the Chromatographic Method

\begin{tabular}{c|c|c|c|c|c}
\hline S. No. & Parameter & Ombitasvir & Paritaprevir & Ritonavir & Limits \\
\hline 1 & Retention factor & 5.8 & 6.4 & 3.2 & $\begin{array}{c}\text { Not deviate by 10\% of actual } \\
\text { RT }\end{array}$ \\
\hline 2 & Theatrical plates & 5973 & 5610 & 3150 & NLT 2000 \\
\hline 3 & Tailing factor & 1.2 & 1.3 & 1.4 & NMT 2 \\
\hline 4 & Resolution & & 2.3 & 11.0 & NLT 2 \\
\hline
\end{tabular}

\section{Robustness}

It is a measure of its capacity to remain unaffected by small, but deliberate variations in method parameters. It provides an indication that the method was reliable. The analytical method was checked for the following parameters:

1. Effect of organic phase composition $( \pm 3 \%$ mobile phase variation $)$

2. Effect of mobile phase flow rate $( \pm 0.1 \mathrm{~mL} / \mathrm{min})$

3. Effect of temperature $( \pm 5 \mathrm{~nm})$

The data obtained for robustness studies were given in Table-9.

\section{Analysis of The Marketed Formulation}

The proposed method was evaluated by the assay of the commercially available tablet dosage form (TECHNIVIE) containing ombitasvir $(12.5 \mathrm{mg})$, Paritaprevir $(75 \mathrm{mg})$ and Ritonavir $(50 \mathrm{mg})$. The $\%$ assay of ombitasvir, Paritaprevir and Ritonavir was found to be $99.75 \%$ and $100.26 \%$ and $99.93 \%$, respectively. The $\%$ RSD was less than 2 , which indicates accuracy of the proposed method. The assay chromatograms of ombitasvir and Paritaprevir and Ritonavir in working standard and working sample solution were shown in Figs.-5 and 6.

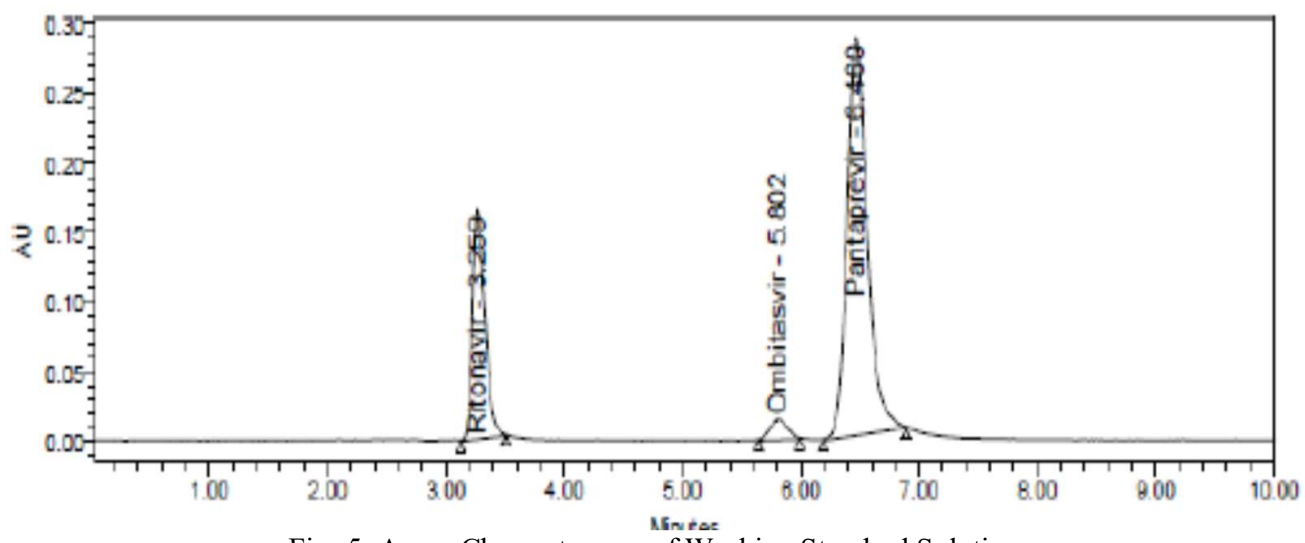

Fig.-5: Assay Chromatogram of Working Standard Solution

Table-9: Data for Robustness Evaluation

\begin{tabular}{c|c|c|c|c}
\hline S. No. & Parameter & \%RSD of Ritonavir & \%RSD of Ombitasvir & \%RSD of Paritaprevir \\
\hline 1 & Flow rate (-) & 0.6 & 1.1 & 0.8 \\
\hline 2 & Flow rate (+) & 0.6 & 0.4 & 0.8 \\
\hline 3 & Mobile phase (-) & 0.8 & 0.8 & 0.7 \\
\hline 4 & Mobile phase (+) & 0.4 & 1.0 & 0.5 \\
\hline 5 & Temperature (-) & 0.5 & 0.9 & 0.7 \\
\hline 6 & Temperature (+) & 0.8 & 0.5 & 1.0 \\
\hline
\end{tabular}


RASĀYAN J. Chem.

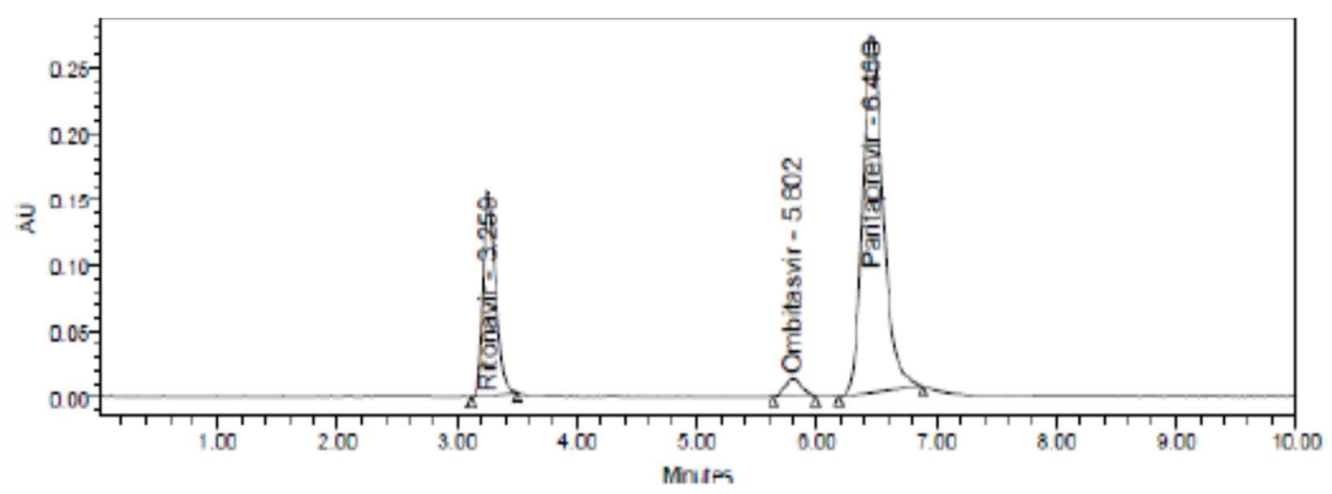

Fig.-6: Assay Chromatogram of Working Sample Solution

Table-10: Assay Data of Ombitasvir, Paritaprevir, and Ritonavir

\begin{tabular}{c|c|c|c|c}
\hline & Parameter & Std. Area & Sample Area & \%Assay \\
\hline \multirow{4}{*}{ Ombitasvir } & Average area & 130773 & 130701 & 99.75 \\
\cline { 2 - 5 } & SD & 553.2 & 497.3 & 0.38 \\
\cline { 2 - 5 } & \%RSD & 0.4 & 0.4 & 0.4 \\
\hline \multirow{4}{*}{ Paritaprevir } & Average area & 2072309 & 2079838 & 100.26 \\
\cline { 2 - 5 } & SD & 16095.6 & 17687.6 & 0.853 \\
\cline { 2 - 5 } & \%RSD & 0.8 & 1167482 & 0.9 \\
\hline \multirow{7}{*}{ Ritonavir } & Average area & 1165982 & 3719.5 & 0.318 \\
\cline { 2 - 5 } & SD & 1998.3 & 0.3 & 0.3 \\
\cline { 2 - 5 } & \%RSD & 0.2 & & \\
\hline
\end{tabular}

\section{Degradation Studies}

A degradation study with the formulation was performed and the degraded samples were injected into the system to calculate the percentage of drug degraded. The results that were given in Table-11 indicate method stability.

Table-11: Degradation Studies of Drugs

\begin{tabular}{c|c|c|c|c}
\hline S. No. & Degradation Condition & $\begin{array}{c}\text { Ombitasvir(\% drug } \\
\text { degraded) }\end{array}$ & Paritaprevir & Ritonavir \\
\hline 1 & Acid & 8.40 & 8.20 & 9.12 \\
\hline 2 & Alkali & 8.58 & 6.62 & 7.49 \\
\hline 3 & Oxidation & 7.76 & 4.39 & 5.78 \\
\hline 4 & Thermal & 4.36 & 3.04 & 2.86 \\
\hline 5 & UV & 1.51 & 1.16 & 1.73 \\
\hline 6 & Water & 0.60 & 0.26 & 0.71 \\
\hline
\end{tabular}

\section{Comparative Studies}

To avidly demarcate the pros and cons of using AQbD approach we have developed a method and validated it as per guidelines. The method was also used for studying drug formulations and stability details. We compared the data with some peer-reviewed journals and the results were presented in Table12,13 and 14.The Numbers indicate science-based approach helps in getting reciprocate values to peers with less number of attempts but it requires proficiency in truly understanding the concepts and applying them. ${ }^{12,23,24}$

Table-12: Comparative Studies of Results Obtained by AQBD to Other Traditional Approaches from the Literature

\begin{tabular}{c|c|c|c|c}
\hline & Ibrahim Baje $^{23}$ & Jahnavi Bandla $^{24}$ & AL-Zoman $^{12}$ & Present Method \\
\hline \multirow{2}{*}{ Retention time } & 3.491 & 5.594 & 6.388 & 5.8 \\
\cline { 2 - 5 } & 4.120 & 2.377 & 1.476 & 6.4 \\
\cline { 2 - 5 } & 2.598 & 3.194 & 3.499 & 3.2 \\
\hline \multirow{2}{*}{$\begin{array}{c}\text { Theoretical } \\
\text { Plates }\end{array}$} & & 9156 & 6632 & 5973 \\
\cline { 2 - 5 } & & 4726 & 2443 & 5610 \\
\hline
\end{tabular}


RASĀYAN J. Chem.

Vol. 14 | No. 2 |799-810| April - June | 2021

\begin{tabular}{c|c|c|c|c}
\hline & & 6741 & 5555 & 3150 \\
\hline \multirow{3}{*}{ Resolution } & & 11.99 & 6.64 & - \\
\cline { 2 - 5 } & & - & - & 2.3 \\
\cline { 2 - 5 } & & 5.43 & 4.25 & 11.0 \\
\hline \multirow{2}{*}{ Tailing Factor } & & 0.98 & 1.2 & 1.2 \\
\cline { 2 - 5 } & & 1.05 & 1 & 1.3 \\
\cline { 2 - 5 } & & 1.16 & 1 & 1.4 \\
\hline
\end{tabular}

Table-13: Comparison of Validation Parameters of Present Method with other Traditional Methods

\begin{tabular}{|c|c|c|c|c|}
\hline \multirow[t]{3}{*}{ Linearity $\left(\mathrm{r}^{2}\right)$} & 0.999 & 0.9993 & 0.9997 & 0.999 \\
\hline & 0.999 & 0.9992 & 0.9995 & 0.9998 \\
\hline & 0.999 & 0.9995 & 0.9996 & 0.999 \\
\hline \multirow[t]{3}{*}{ Accuracy } & $99.80 \pm 0.64$ & $98.88-99.80$ & $101.64 \pm 0.006$ & 99.94 \\
\hline & $99.66 \pm 0.52$ & $99.62-100.05$ & $101.39 \pm 0.250$ & 100.24 \\
\hline & $99.5 \pm 0.36$ & $99.38-100.28$ & $100.92 \pm 0.053$ & 99.83 \\
\hline \multirow[t]{3}{*}{ Precision(RSD) } & 0.5 & 0.3 & 0.006 & 0.3 \\
\hline & 1.1 & 0.4 & 0.247 & 0.4 \\
\hline & 0.6 & 0,2 & 0.053 & 0.9 \\
\hline \multirow[t]{3}{*}{$\mathrm{LOD}(\mu \mathrm{g} / \mathrm{ml})$} & 0.019 & 0.34 & 0.0065 & 0.004 \\
\hline & 0.02 & 0.17 & 0.0024 & 0.107 \\
\hline & 0.02 & 0.31 & 0.0521 & 0.023 \\
\hline \multirow[t]{3}{*}{$\mathrm{LOQ}(\mu \mathrm{g} / \mathrm{ml})$} & 0.06 & 1.04 & 0.0130 & 0.0121 \\
\hline & 0.07 & 0.52 & 0.0049 & 0.324 \\
\hline & 0.07 & 0.93 & 0.1042 & 0.069 \\
\hline \multirow[t]{3}{*}{ ASSAY } & & & $102.28 \pm 0.011$ & $99.75 \pm 0.38$ \\
\hline & & & $101.89 \pm 0.264$ & $100.26 \pm 0.853$ \\
\hline & & & $101.93 \pm 0.862$ & $99.93 \pm 0.318$ \\
\hline
\end{tabular}

Table-14: Degradation Studies of AQBD Method to Traditional Method

\begin{tabular}{c|c|c}
\hline Method(Purity Thresold) & Jahnavi Bandla $^{24}$ & Present Method \\
\hline \multirow{4}{*}{ Acid } & 0.305 & 2.673 \\
\cline { 2 - 3 } & 0.308 & 0.329 \\
\cline { 2 - 3 } & 0.741 & 0.339 \\
\hline \multirow{4}{*}{ Alkali } & 0.283 & 2.869 \\
\cline { 2 - 3 } & 0.381 & 0.337 \\
\hline \multirow{4}{*}{ Oxidation } & 1.561 & 0.359 \\
\cline { 2 - 3 } & 0.296 & 8.605 \\
\cline { 2 - 3 } & 0.390 & 0.344 \\
\hline \multirow{5}{*}{ Thermal } & 1.574 & 0.328 \\
\cline { 2 - 3 } & 0.290 & 2.853 \\
\cline { 2 - 3 } & 0.540 & 0.310 \\
\hline \multirow{5}{*}{ UV } & 3.719 & 0.320 \\
\cline { 2 - 3 } & 0.291 & 2.616 \\
\cline { 2 - 3 } & 0.540 & 0.306 \\
\hline \multirow{4}{*}{ Water } & 3.725 & 0.315 \\
\cline { 2 - 3 } & 0.290 & 2.684 \\
\cline { 2 - 3 } & 0.597 & 0.306 \\
\hline \multirow{4}{*}{} & 4.230 & \\
\hline
\end{tabular}

\section{CONCLUSION}

A robust, simple, rapid and sensitive RP-HPLC method for identification of critical attributes by QbD approach for the three anti-viral drugs was developed and validated as per ICH guidelines. It poses an indepth understanding of the method and imparts quality during the development phase of the method to ensure optimum performance. It was highly accomplished by analytical chemists. It can be used for routine simultaneous analysis of selected drugs in the dosage form. 
RASĀYAN J. Chem.

Vol. 14 | No. 2 |799-810| April - June | 2021

\section{ACKNOWLEDGMENT}

We are very thankful to Hetero Drugs Pvt Ltd Hyderabad for providing the samples of the drug. The continuous support of the management of Sir C R Reddy College of Pharmaceutical Sciences, Eluru, Andhra Pradesh and Gokaraju and Rangaraju College of Pharmacy, Hyderabad Telangana also helped us accomplish this project

\section{REFERENCES}

1. A.H Beckett, J.B. Stanlake, Practical Pharmaceutical Chemistry, CBS Publishers and Distributors, Delhi, p.78, 91(2002), DOI:10.1002/jps.2600520537

2. R.G. Chatwal, Instrumental Methods of Chemical Analysis, Himalaya Publishers, Mumbai. (2010)

3. R.G. Corners, Textbook of Pharmaceutical Analysis, Wiley- Inter Science Publication, Delhi, (1967), DOI: $10.1021 /$ ed045pA64.2

4. https://www.drugbank.ca/drugs/DB09296

5. https://www.drugbank.ca/drugs/DB09297

6. https://www.scbt.com/scbt/product/ritonavir-155213-67-5

7. J. Andrew, Journal of Biochemistry, 8, 1353 (2016), DOI:10.4155/bio-2016-0040

8. M.Jagadeeswaran, Pharmaceutical Analytical Acta, 3, 5 (2012), DOI:10.4172/2153-2435.1000160

9. A.V. Kasture, S.G Wadodkar, K.R Mahadik, Textbook of Pharmaceutical Analysis-II, Nirali Prakashan Publishers, Mumbai(2005).

10. K.Mangamma, D.Gowri sankar, Asian Journal of Chemistry, 30(6), 1277(2018), DOI: 10.14233 /ajchem.2018.21215

11. G.Kranthi Kiran, K.Srinivasa Rao, A.Gowri Shankar, International Journal of Medicinal Chemistry and Analysis, 7, 63 (2017), DOI:10.21276/ijmca.2017.7.2.4

12. Magdy Atef Wadie, Samia Mahumoud Mostafa, IOSR-Journal of Pharmacy and Biological Sciences, 12, 28 (2017), DOI: 10.9790/3008-1205036068

13. Nourah ZomanAl-Zoman, Chemistry Central Journal, 7(11), 1 (2017), DOI:10.1186/s13065-0160232-6

14. R. Peraman, K. Bhadraya, Y. Padmanabha reddy, T. Lokesh, Indian Journal of Pharmaceutical Sciences, 6, 751(2015), DOI:10.4103/0250-474X.174971

15. A.Satinder and M.W. Dong, Method Development and Validation, Pharmaceutical Analysis by HPLC, Ahuja Publishes, Newyork (2005), DOI:10.1016/S0149-6395 (05)80050-9

16. A. Skoog and J. Holler, Fundamentals of Analytical Chemistry, Saunders College Publishing, Philadelphia (1992), DOI:10.1021/ed040p614.2

17. K.Sharma, High Performance Liquid Chromatography- Instrumental Methods of Chemical Analysis, Goel Publishers, Meerut (2005).

18. N.Shivanand, Journal of Taibah University Medical Sciences, 10(3),271(2015), DOI:10.1016/j.jtumed.2014.11.006

19. R.L Snyder, and J.J kirklannd, Practical HPLC Method Development, CBS Publishers, New York (1997).

20. M.E Swartz, Analytical Method Development and Validation, Marcel Dekker Publishers, New York (2009).

21. Y. Usami, and M. Sagisaka, M. Kaneda, Chemical and Pharmaceutical Bulletin, 51, 715 (2003), DOI: $10.1248 / \mathrm{cpb} .51 .715$

22. M. Useni Reddy, Oriental Journal of Chemistry, 33, 2363(2017), DOI:10.13005/ojc/330528

23. Syed Ibrahim Baje, B. Jyothi ,N. Madhavi, International Journal of Applied Pharmectics,11,193 (2019), DOI:10.22159/ijap.2019v11i2.28141

24. J. Bandla, Asian Journal of Pharmaceutical Education and Research, 7, 1, 90(2017).

25. ICH: Q2 (R1), Validation of Analytical Procedures: Text and Methodology, November 2005.

[RJC-6139/2020] 